\title{
CONTAMINATION OF SOIL AND VEGETATION AT A MAGNESITE MINING AREA IN JELŠAVA-LUBENÍK (SLOVAKIA)
}

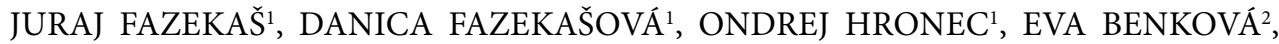 \\ MARTIN BOLTIŽIAR ${ }^{3}$
}

${ }^{1}$ Department of Environmental Management, Faculty of Management, University of Prešov, Konštantínova 16, 08001 Prešov, Slovak Republic; e-mail: juraj.fazekas@smail.unipo.sk, danica.fazekasova@unipo.sk, ondrej. hronec@unipo.sk

${ }^{2}$ Department of Intercultural Communication, Faculty of Management, University of Prešov, Konštantínova 16, 08001 Prešov, Slovak Republic; e-mail: eva.benkova@unipo.sk

${ }^{3}$ Institute of Landscape Ecology, Slovak Academy of Sciences, Bratislava, branch Nitra, Akademická 2, 94901 Nitra, Slovak Republic; e-mail: martin.boltiziar@savba.sk

\begin{abstract}
Fazekaš J., Fazekašová D., Hronec O., Benková E., Boltižiar M.: Contamination of soil and vegetation at a magnesite mining area of Jelšava-Lubeník (Slovakia). Ekológia (Bratislava), Vol. 37, No. 2, p. 101-111, 2018

This paper is focused on the impacts of alkaline and metal deposition on soil and vegetation in the immission field of magnesium factory Jelšava-Lubeník (Slovakia). Soil samples and the foliage of vegetation were obtained from the Jelšava-Lubeník area with specific alkaline pollutants. The examined area is one of the most devastated regions of Slovakia. From the point of view of environmental regionalization, it belongs to an environmentally damaged area of Category 3 . The total content of heavy metals in the soil and vegetation $(\mathrm{Pb}, \mathrm{Zn}, \mathrm{Cr}, \mathrm{Mn}, \mathrm{Mg}$ ) were determined by atomic absorption spectrometry and X-ray fluorescence spectrometry. Soil reaction was determined in a solution of $0.01 \mathrm{M} \mathrm{CaCl}_{2}$. Vegetation was assessed by the Braun-Blanquet scale. In conclusion, we can say that spray particles of free magnesium oxide $(\mathrm{MgO})$ strongly influence soil reaction, diversity, and vegetation cover. The research showed that the investigated sites were mostly strongly alkaline; the contents of $\mathrm{Cr}, \mathrm{Mn}$ and $\mathrm{Mg}$ were over the toxicity limit, while the measured values of $\mathrm{Pb}$ and $\mathrm{Zn}$ did not exceed the limits set by the law. The values that measured significantly above the set limit show contamination that can be considered harmful and toxic. In the monitored species, that is, Agrostis stolonifera, Elytrigia repens and Phragmites australis, an over-limit content of $\mathrm{Pb}$ and $\mathrm{Zn}$ and toxic contents of $\mathrm{Mg}$ and $\mathrm{Mn}$ were found.
\end{abstract}

Key words: magnesium, manganese, soil reaction, Phragmites australis, Elytrigia repents, Agrostis stolonifera.

\section{Introduction}

Anthropogenic activities, such as fossil fuel burning, mining and smelting of ores, domestic mobile sources (automotive industry) and industrial waste, organic and mineral fertilizers, liming and pesticides, and sludge from sewage treatment cause serious pollution of the 
biosphere by releasing toxic heavy metals that often have toxic effects on the environment (Mahmood, 2010; Adriano, 2001). Soil does not emerge as a passive acceptor of heavy metals; polluted soil is a source of pollution of the other components of environment and food chain (Singh et al., 2006). In relation to nature, the results of economic activities of anthropogenic activities are acidification, alkalization and metallization elements of the environment (Hronec et al., 2008; Fazekašová et al., 2014; Mindáš, Škvarenina, 1995). Heavy metals can accumulate in various plant parts, depending on the plant species, soil condition, and the type of heavy metal (Barman et al., 2001). Plants' ability to cope with an excessive amount of heavy metals varies. Some plant species have mechanisms that impose heavy metals on cell walls or bond them chemically in the vacuole, thus reducing their toxicity. Others impede penetration of heavy metals from the roots to the above-ground parts. Accumulators are such plants species that accumulate a large amount of specific metals in their tissues (Pant, Tripathi, 2014). Agrostis capillaris, Calamagrostis epigejos, Deschampsia flexuosa and Agrostis stolonifera are capable of forming tolerant ecotypes. Elytrigia repens and Taraxacum officinale are also characterized by a high ecological valence and resistance to heavy metals (Banásová, 2004; Boguská et al., 2013). Phragmites australis is considered as a plant with a high detoxification and phytoremediation potential and has been widely used in wetlands for the treatment of industrial wastewater containing heavy metals. Therefore, much attention has recently been focused on the response of this plant to heavy metal stresses (Jiang, Wang, 2008). Some plants possess super-accumulative properties with regard to heavy metals: they can accumulate up to $5 \%$ of heavy metals (nickel, zinc or copper) in their leaves (as dry mass), which is more than tenfold higher than the values for ordinary plants (Gladkov et al., 2011). Soil parameter such as soil reaction, the organic matter content and quality, soil sorption complex, soil granularity, and oxidation-reduction potential influence the availability of heavy metals in plants (Wang et al., 2015). Soil alkalinity is conditioned by the presence of alkaline salts, which are easily hydrolysed and allow the formation of alkalinity. The fundamental reason of soil alkalinity is the presence of exchangeable sodium and the content of $\mathrm{Na}_{2} \mathrm{CO}_{3}$ or $\mathrm{NaHCO}_{3}$ in soil solutions that worsen some soil processes like soil acidity. A strong alkaline reaction of $\mathrm{pH} / \mathrm{CaCl}_{2}>7.7$ is created by air alkaline pollutants from a magnesium factory. Magnesite air pollutants are a mixture of $\mathrm{MgO}$ and $\mathrm{MgCO}_{3}$, due to which a soil reaction can move above $\mathrm{pH} 8$ (Baluchová et al., 2011).

This paper examines the impacts of alkaline and metal deposition on soil and vegetation in the immission field of magnesium factory Jelšava-Lubeník (Slovakia).

\section{Material and methods}

Study area

Jelšava and Lubeník lie in the south-central part of the Slovak Ore Mountains in the Muran valley, in the district called Jelšava podolie. Jelšava podolie, geomorphologically, belongs to the Revúca Highlands (Mazúr, Lukniš, 1980). Geologically, the area belongs to the Central Western Carpathians. The area is built mainly by Palaeozoic and Mesozoic rocks. Palaeozoic rocks are found in a wide belt between Jelšava and Lubeník, and consist of phyllites, sandstones, shales, limestones and conglomerates. The soil type of Cambisol evolved on this bedrock-it is lightly skeletal, mostly of medium depth $(60-120 \mathrm{~cm})$, and the steeper slopes are prone to erosion. The original reaction soil $\mathrm{pH}$ of about 5 was changed to a $\mathrm{pH}$ of about 7.2 to 8.5 due to magnesite dust contamination. The second largest group of rocks consists of limestone, dolomite, and slate limestone, which we categorize as Mesozoic rocks. The 
developed soils are mostly shallow $(15-20 \mathrm{~cm})$, loam to loamy clay, predominantly strongly skeletal, and classified as Rendzinas. The third group consists of rocks of the upper Pliocene sediments-they are clays, sands, and gravels with overlays of quaternary clays, in which there were developed Luvisols. Fluvisols and their various subtypes are developed in the alluvium of the river Muran (Hronec et al., 2010).

Jelšava and Lubeník belong to a warm climatic region with 50 and more summer days (a summer day has a maximum air temperature $25^{\circ} \mathrm{C}$ ). The climate is warm, moderately humid with a cold winter. The average temperature in January is -3 to $-5^{\circ} \mathrm{C}$ and in July 14.5 to $16.5^{\circ} \mathrm{C}$. Annual precipitation is $600-800 \mathrm{~mm}$ (Climate Atlas of Slovakia, 2015). Based on the values of the Gorczynski index, the study area belongs to the transitional maritime climate (Vilček et al., 2016), where the actual evapotranspiration value reaches $400-450 \mathrm{~mm}$ per year (Škvarenina et al., 2009).

Twelve research sites of the problem area Jelšava (N48³8'39.1" E20¹3'02.7”) and Lubeník (N48³9'18.3" E20 $\left.0^{\circ} 11^{\prime} 48.9^{\prime \prime}\right)$ were monitored in the agrarian country (Fig. 1). Soil samples were collected from the permanent research sites, which are used as permanent grasslands and are in the immission field of the magnesium factory, Jelšava-Lubeník (Slovakia), from the A horizon to the depth of 0.05 to $0.15 \mathrm{~m}$.

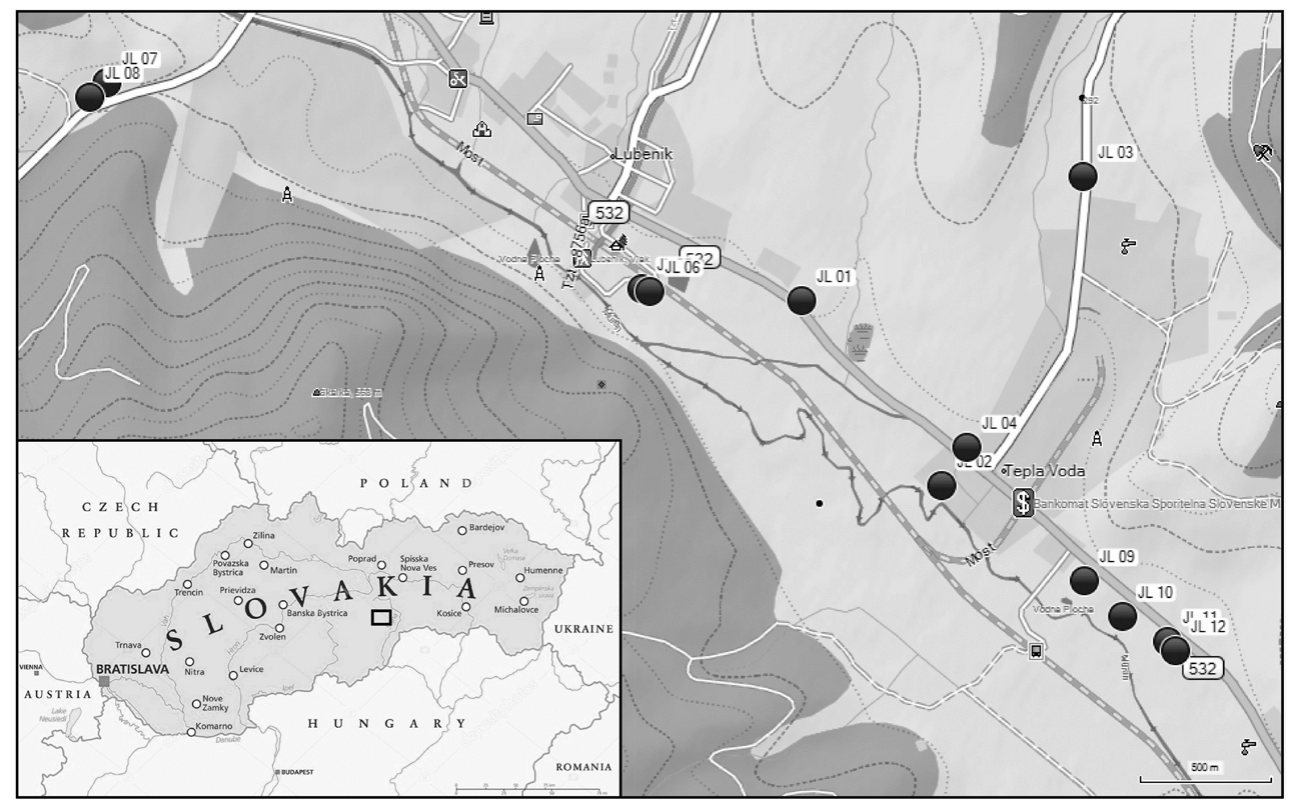

Fig. 1. Location of research sites in the investigated areas of Jelšava and Lubeník (Slovakia).

\section{Soil assays}

After homogenization, the soil samples were manually crumbled, dried at room temperature, sieved $(<2 \mathrm{~mm})$ and stored in polyethylene bags until the analysis. We studied and evaluated the soil reaction in a $1 \mathrm{~N}$ solution $\mathrm{CaCl}_{2}$ ( $5 \mathrm{~g}$ of soil mixed with $25 \mathrm{ml}$ of $0.01 \mathrm{M} \mathrm{CaCl}_{2}$ ) using the Mettler Toledo $\mathrm{pH}$ meter. The total content of $\mathrm{Pb}, \mathrm{Zn}, \mathrm{Cr}$, $\mathrm{Mn}$ and $\mathrm{Mg}$ was determined by X-Ray fluorescence spectrometry following the methodology as devised by Fiala et al. (1999). The assessed values of heavy metals in soils were compared to the limit values of Slovak soils (Act No. 220/2004). 
The foliage of Pragmites australis, Elytrigia repents and Agrostis stolonifera was collected to determine the heavy metal content. Vegetation samples were dried at $40^{\circ} \mathrm{C}$, homogenised to the fraction $<0.09 \mathrm{~mm}$, burned in a furnace at $550^{\circ} \mathrm{C}$ and decomposed with a mixture of $\mathrm{HCl}$ and $\mathrm{HNO}$ acid. The concentration of heavy metals was $(\mathrm{Pb}, \mathrm{Zn}, \mathrm{Cr}$, $\mathrm{Mn}, \mathrm{Mg}$ ) determined and the measured values of heavy metals were compared with the threshold values of plants determined by law (Act No. 220/2004). The samples were analysed by atomic absorption spectrometry, and X-ray fluorescence spectrometry following the methodology devised by Fiala et al. (1999).

The diversity of grassland communities was monitored in the form of plots on the field of $16 \mathrm{~m}^{2}$ during the 2016 growing season. Vegetation was assessed by the Braun-Blanquet scale (Braun-Blanquet, 1964). The terminology is given in accordance with Marhold, Hindák (1998). The determination of the species diversity of the sites was done according to the Shannon index:

$$
H^{\prime}=-\sum_{i=1}^{s} \frac{x i}{N} \log 2 \frac{x i}{N}
$$

which is sensitive to the different characteristics of plant communities, particularly the number and significance of the coefficient of all kinds. The results were evaluated on the basis of scales: 1 extremely low $(<0.5), 2$ very low (0.5-1), 3 middle low (1-1.7), 4 low (1.7-2.5), 5 low to moderate (2.5-3.3), 6 medium (3.3-4), 7 half-height (4-5), 8 high (5-7), 9 very high (7-10) and 10 extremely high $(>10)$.

\section{Statistical analysis}

The obtained data were processed statistically with the Statistica 13 software and PAST 3. The level of significance between soil properties was calculated using the Spearman's correlation coefficient. The data were LOG-transformed prior to the analysis.

\section{Results and discussion}

\section{Soil reaction}

Soil reaction is considered to be one of the main chemical properties because it affects all biochemical reactions in the soil environment (Hohl, Varma, 2010). The mobility, translocation, and toxic effects of risk elements are affected by some soil properties, the content of the clay, organic matter, and soil reaction (Song et al., 2006). The soil reaction in the alkali-contaminated areas of Jelšava and Lubeník ranged between $7.95 \pm 1.03$ (median \pm standard deviation) (Table 1, Fig. 2). Mg flings with significant reactive caustic magnesite are aggressive in natural environments, as even small quantities coming into contact with the soil and crop moisture form saturated solutions with a high alkaline $\mathrm{pH}$ value (Baluchová et al., 2011).

\section{Heavy metal pollution in soil}

The content of lead $(\mathrm{Pb})$ and zinc $(\mathrm{Zn})$ in the studied area did not exceed the values set by the law (Act NO. 220/2004). The average values of $\mathrm{Pb}$ on the examined area were under the limit, ranging from $17-45 \mathrm{mg} \mathrm{kg}^{-1}$. The average content of $\mathrm{Zn}$ varies in the region around 32 $\mathrm{mg} \mathrm{kg}^{-1}$, a value under the limit. The chromium content in the soil of the investigated area, Jelšava and Lubeník, was in the range of $140.00 \pm 279.49$ (median \pm standard deviation), considerably exceeding the values determined by the law (Table 1, Fig. 2). The median level 
$\mathrm{T} \mathrm{a} \mathrm{b} \mathrm{l} \mathrm{e} \mathrm{1.} \mathrm{Variance} \mathrm{analyses} \mathrm{of} \mathrm{heavy} \mathrm{metals}\left(\mathrm{mg} \mathrm{kg}^{-1}\right)$ and soil reaction of the investigated areas in Jelšava and Lubeník (Slovakia).

\begin{tabular}{|l|c|c|c|c|c|c|}
\hline Parameter & Mean & Median & Min & Max & Std. Dev. & ${ }^{\star}$ Limit value \\
\hline $\mathbf{p H} / \mathbf{C a C l}_{\mathbf{2}}$ & 7.63 & 7.95 & 6.20 & 8.80 & 1.03 & \\
\hline $\mathbf{P b}\left(\mathbf{m g ~ k g}^{-1}\right)$ & 32.42 & 32.00 & 17.00 & 45.00 & 8.16 & 70 \\
\hline $\mathbf{C r}\left(\mathbf{m g ~ k g}^{-1}\right)$ & 231.08 & 140.00 & 83.00 & 1055.00 & 279.49 & 70 \\
\hline $\mathbf{Z n}\left(\mathbf{m g ~ k g}^{-1}\right)$ & 88.33 & 88.50 & 48.00 & 108.00 & 15.17 & 150 \\
\hline $\mathbf{M n}\left(\mathbf{m g ~ k g}^{-1}\right)$ & 1575.00 & 1600.00 & 800.00 & 2300.00 & 517.20 & \\
\hline $\mathbf{M g}\left(\mathbf{m g ~ k g}^{-1}\right)$ & 49841.67 & 26150.00 & 7000.00 & 197000.00 & 59039.25 & \\
\hline
\end{tabular}

Note: ${ }^{\star A c t}$ No. $220 / 2004$ Coll. of Laws.

of chromium in the soil of Slovakia was $85 \mathrm{mg} \mathrm{kg}^{-1}$ in the A-horizon (Ševčík et al., 2008). However, the data presented by Čurlík, Šefčík (1999) indicate high Cr levels (up to 6096 $\mathrm{mg} \mathrm{kg}^{-1}$ ) in both A and C horizons of soils from the Outer Carpathians. The major part of $\mathrm{Cr}$ was in a little mobile form in the soil. The mobility depended on the $\mathrm{pH}$, the content of clay particles, and the redox potential of the soil. Chromium, cobalt and nickel are considered as metals that come from a geogenic load (Takáč et al., 2008). Hexavalent chromium $\left(\mathrm{Cr}^{6+}\right)$ is classified as one of the most important environmental contaminants (Kafka, Punčochárová, 2002). Readily soluble $\mathrm{Cr}^{6+}$ in soils is toxic to plants and animals. A dose of $0.5 \mathrm{~g}$ chromium dioxide kills a man and is classified as a human carcinogen (Melichová et al., 2017). Therefore, the variability in the oxidation states of $\mathrm{Cr}$ in soils is of a great environmental concern (Kabata-Pendias, 2011). Chromium is a heavy metal of high environmental impact (Vaiopoulou, Gikas, 2012), as it can severely affect the behaviour of micro- and macroorganisms (Gikas, Romanos, 2006; Shanker et al., 2005).

Magnesium is considered the fifth major nutrient in plant nutrition and is not present within the hygienic limits set by the Slovak Republic. The Mg content highly significantly correlates with soil texture, soil reaction, soil potassium content, and soil sorption capacity (Fazekašová et al., 2014). It is located in several primary and secondary minerals. The content values of the magnesium found in the topsoil of agricultural land in Slovakia are in the range of 200-400 mg kg-1, showing a high content of this element in the soil (Kobza et al., 2010). Therefore, the values over $500 \mathrm{mg} \mathrm{kg}^{-1}$ can be considered as higher to high, or over the limit (over $1000 \mathrm{mg} \mathrm{kg}^{-1}$ ). In the studied area, we found significant contamination of soil by magnesium with values within the range of $26150.00 \pm 59039.25$ (median \pm standard deviation), which is, on average, 18 to 493 times in excess (Table 1, Fig. 2). From the measured data of $\mathrm{Mg}$ content in the soil, it is possible to conclude the presence of a considerable heterogeneity, which is confirmed by a significant difference between the minimum and maximum values. The highest concentrations of Mg exceeded the high content of this element 492.5 times, which is comparable with Wang et al. (2015). The Mg content above the limit has a toxic influence on plants, causing their gradual necrosis and loss of soil vegetation cover.

The measured levels of manganese had a similar pattern and contents in the range $1600.00 \pm 517.20$ (median \pm standard deviation) (Table 1, Fig. 2). The average content of manganese in the soil of the Slovak Republic is in the range of 0.85 to $112.90 \mathrm{mg} \mathrm{kg}^{-1}$, indicating a significant spatial heterogeneity of the elements, but a medium supply of this element 

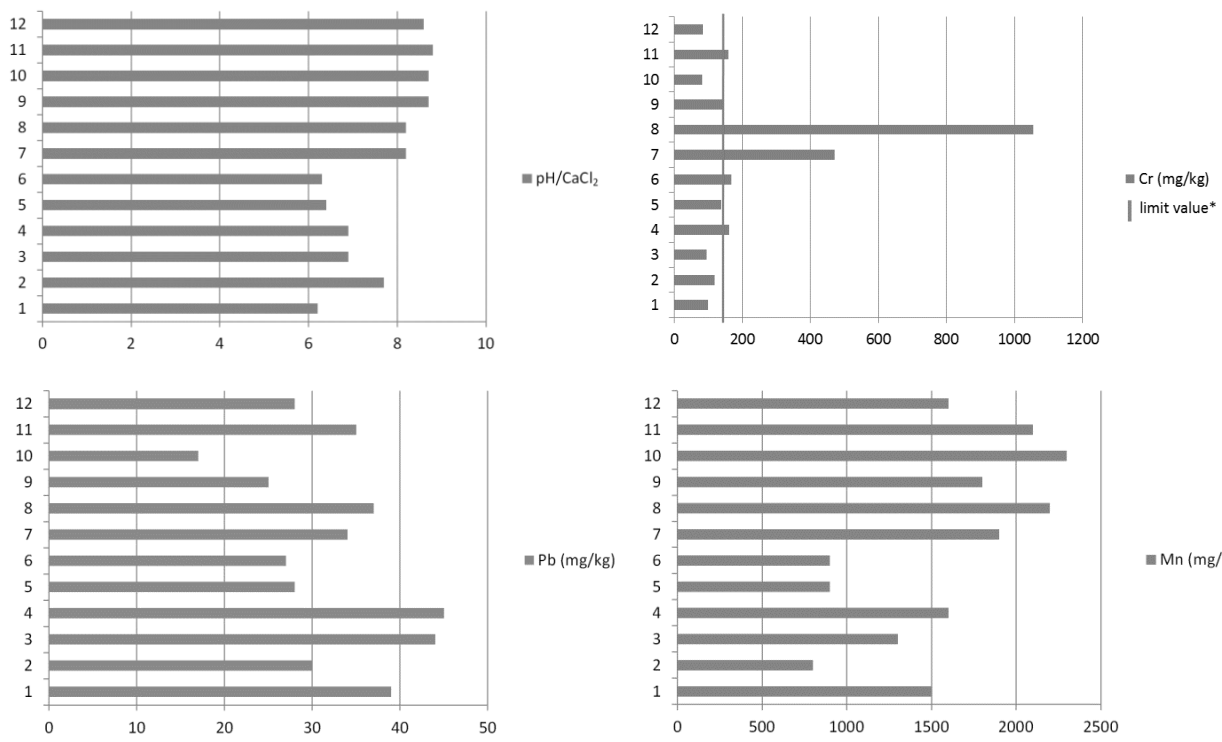

$\mathrm{Mn}(\mathrm{mg} / \mathrm{kg})$
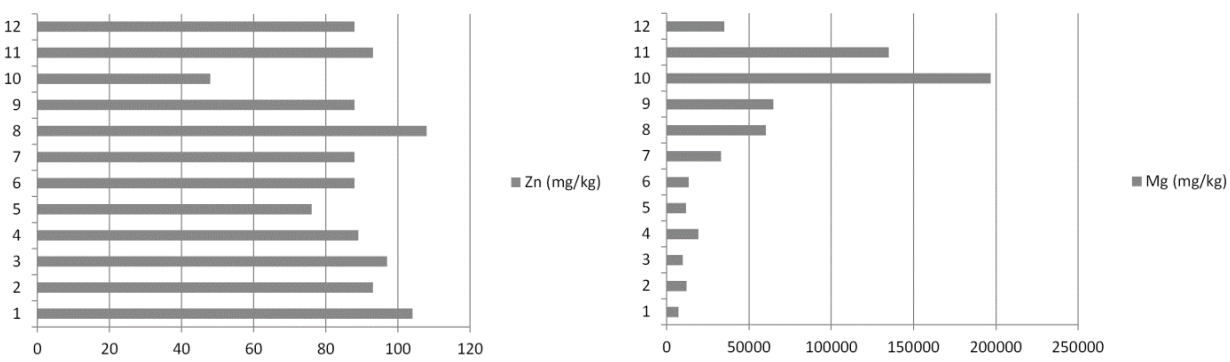

Fig. 2. Values of soil reaction and heavy metal content in soil measured in the investigated areas of Jelšava and Lubeník (Slovakia).

Note: ${ }^{\star A c t ~ N o . ~ 220 / 2004 ~ C o l l . ~ o f ~ L a w s . ~}$

dominates the soil. Kabata-Pendias (2011) referred to the value of $1500 \mathrm{mg} \mathrm{kg}^{-1}$, which shows the symptoms of manganese toxicity. The most toxic compounds of manganese are in the oxidation No. III. The lethal dose of potassium permanganate $\left(\mathrm{KMnO}_{4}\right)$ for an adult human is 5 g. Some manganese compounds are potential carcinogens (Melichová et al., 2017). Based on the obtained results, it can be stated that the $\mathrm{Pb}, \mathrm{Zn}$ contents are below the toxic level but that does not apply to $\mathrm{Cr}, \mathrm{Mn}$ and $\mathrm{Mg}$. They significantly exceed the limits, pointing to contamination that can be considered toxic and harmful.

The relationships between heavy metals are listed in Table 2. Spearman's correlation coefficients confirmed a negative correlation between $\mathrm{Pb}-\mathrm{Mg}$ and only $\mathrm{Zn}-\mathrm{Mg}$ was significant. A significant positive correlation $(\mathrm{p}<0.05)$ between soil $\mathrm{pH}-\mathrm{Mn}$ and $\mathrm{pH}-\mathrm{Mg}$ was determined in this study. Positive correlations were detected between $\mathrm{Mn}$ and $\mathrm{Mg}$. 
T a b le 2. Correlations between heavy metals and soil reaction $(\mathrm{pH})$ of the investigated areas in Jelšava and Lubeník (Slovakia).

\begin{tabular}{|l|c|c|c|c|c|}
\hline Parameter & Pb & Zn & Cr & Mn & Mg \\
\hline $\mathbf{p H} / \mathbf{C a C l}_{2}$ & 0.409 & 0.239 & 0.211 & $0.718^{*}$ & $0.696^{*}$ \\
\hline $\mathbf{P b}$ & & $0.723^{*}$ & 0.210 & $0.066^{*}$ & $-0.519^{*}$ \\
\hline $\mathbf{Z n}$ & & & 0.411 & 0.154 & $-0.615^{*}$ \\
\hline $\mathbf{C r}$ & & & & 0.417 & 0.004 \\
\hline $\mathbf{M n}$ & & & & & $0.740^{*}$ \\
\hline
\end{tabular}

Note: $\mathrm{p}<0.05^{*}$.

$\mathrm{T}$ a b 1 e 3. Variance analyses of heavy metals in the plant species (Pragmites australis, Elytrigia repents, Agrostis stolonifera) of the investigated areas in Jelšava and Lubeník (Slovakia).

\begin{tabular}{|l|c|c|c|c|c|c|}
\hline Parameter & Mean & Median & Min & Max & Std. Dev. & ${ }^{\star}$ Limit value \\
\hline $\mathbf{C d ~}\left(\mathbf{m g ~ k g}^{-1}\right)$ & 0.09 & 0.10 & 0.09 & 0.10 & 0.01 & 0.10 \\
\hline $\mathbf{P b}\left(\mathbf{m g ~ k g}^{-1}\right)$ & 1.77 & 3.30 & 1.00 & 3.30 & 1.33 & 0.10 \\
\hline $\mathbf{Z n ~}\left(\mathbf{m g ~ k g}^{-1}\right)$ & 39.63 & 85.00 & 7.80 & 95.00 & 48.13 & 2.00 \\
\hline $\mathbf{C r}\left(\mathbf{m g ~ k g}^{-1}\right)$ & 2.13 & 4.30 & 1.00 & 4.30 & 1.88 & - \\
\hline $\mathbf{M n}\left(\mathbf{m g ~ k g}^{-1}\right)$ & 206.67 & 78.00 & 78.00 & 400.00 & 170.46 & - \\
\hline $\mathbf{M g}\left(\mathbf{m g ~ k g}^{-1}\right)$ & 11162.33 & 21.21 & 5419.00 & 21208.00 & 8729.59 & - \\
\hline
\end{tabular}

Note: ${ }^{\star A c t ~ N o . ~ 220 / 2004 ~ C o l l . ~ o f ~ L a w s . ~}$

\section{Diversity of vegetation and heavy metal pollution}

We found alkaline to strongly alkaline soil reactions in seven investigated sites. This greatly affected the variability of species. Characteristic wild solanaceous such as Elytrigia repens, Chenopodium album, Equisetum arvense were present on farmlands. Permanent grasslands were represented by species typical of wet and waterlogged sites such as Alopecurus pratensis, Lychnis flos-cuculi, Cirsium rivulare, Acetosa pratensis, Archangelica officinalis, Agrostis stolonifera and competitively strong species Elytrigia repens, Phragmites australis, creating monoculture in four locations (9-12) (Fig. 1). Ruderal communities of Tanacetum vulgare, Chenopodium album, Silene vulgaris and rampant invasive taxon Solidago canadensis were recorded in Sites 1 and 5 near arable land and also on permanent grasslands.

Species diversity of flora was investigated in localities evaluated by the Shannon index H', which is sensitive to the different characteristics of plant communities, particularly the coefficient of significance of all kinds (Špulerová et al., 2011, 2016; Barančoková, Barančok, 2015; Barančoková et al., 2017). Based on the results of the Shannon index, we can conclude that the diversity on the investigated sites is extremely low (0.0) to middle low (1.5).

The species were selected on the basis of their significance coefficients at individual sites. $\mathrm{Pb}, \mathrm{Zn}, \mathrm{Cr}, \mathrm{Mn}$ and $\mathrm{Mg}$ were analysed in the plant species. The highest contamination compared to the threshold values was found in Elytrigia repens in which the zinc content exceeded the threshold by 47 times and the lead content by 33 times. Excessive values of zinc were also found in dry matter such as Phragmites australis (Table 3, Fig. 3). 

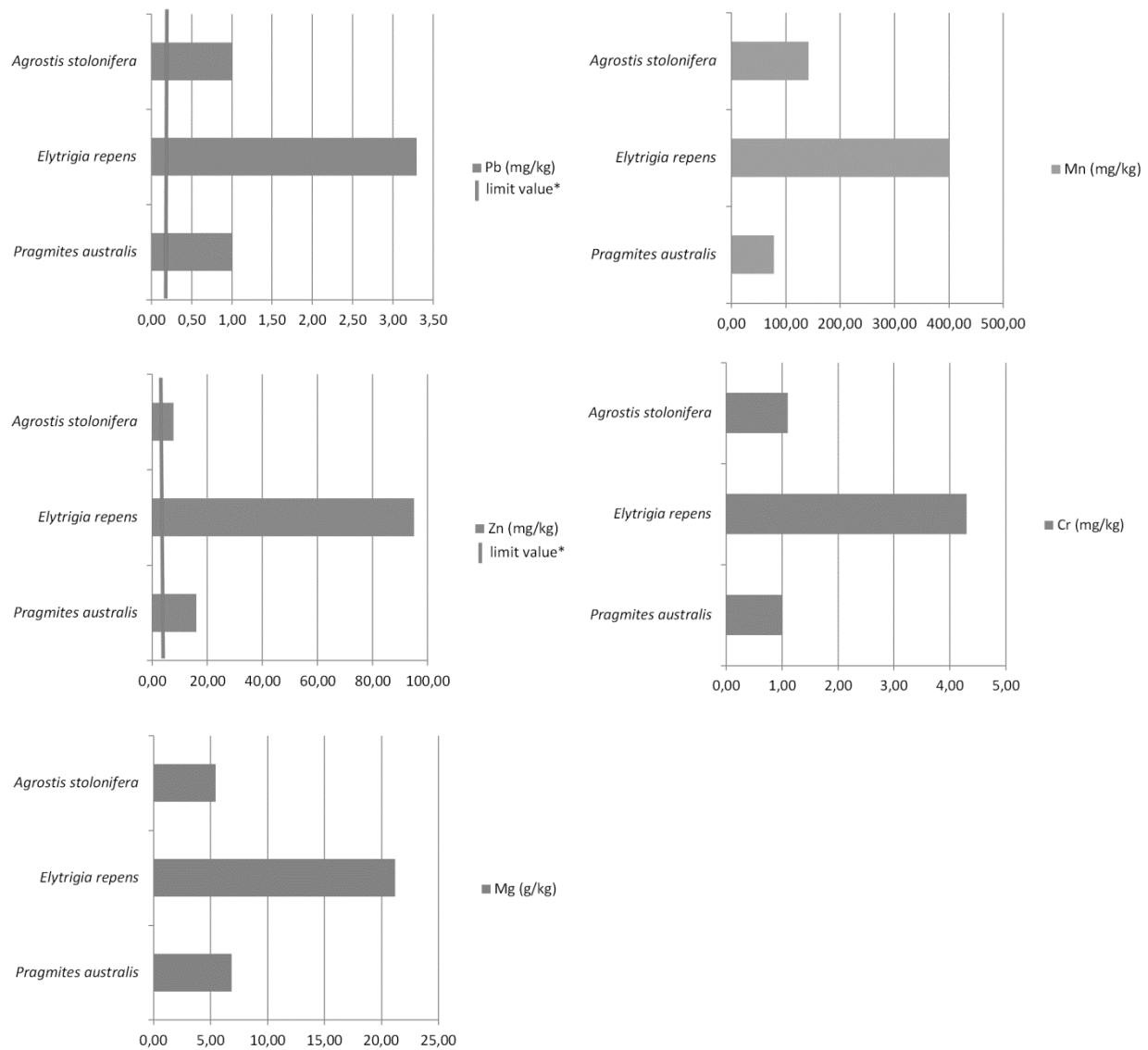

Fig. 3. Heavy metal content in the plant species (Pragmites australis, Elytrigia repents, Agrostis stolonifera) of the investigated areas in Jelšava and Lubeník (Slovakia).

The concentration of magnesium in the sampled plants showed a very high content (Table 3, Fig.). The highest content of the element was found in Elytrigia repens $\left(21208 \mathrm{mg} \mathrm{kg}^{-1}\right)$ $>$ Phragmites australis (6860 mg kg-1) $>$ Agrostis stolonifera (5419 mg kg-1). A high-level of manganese concentration was also found in Elytrigia repens $\left(400 \mathrm{mg} \mathrm{kg}^{-1}\right)>$ Agrostis stolonifera $\left(142 \mathrm{mg} \mathrm{kg}^{-1}\right)>$ Phragmites australis $\left(78 \mathrm{mg} \mathrm{kg}^{-1}\right)$. Most plants are affected by a Mn content above $400 \mathrm{mg} \mathrm{kg}^{-1}$. The accumulation above $1000 \mathrm{mg} \mathrm{kg}^{-1}$ has also been often reported for several more resistant species or genotypes. The hyperaccumulator plants (Phytolacca americana L.) absorbed Mn from the contaminated soil up to $13,400 \mathrm{mg} \mathrm{kg}^{-1}$ in leaves (KabataPendias, 2011). Excess magnesium induced some toxicity symptoms. The plant that received $10,000 \mathrm{mg}$ of $\mathrm{Mg}^{2+} \mathrm{kg}^{-1}$ died on the 20th day after the treatment, and the plants that received $5,000 \mathrm{mg}$ of $\mathrm{Mg}^{2+} \mathrm{kg}^{-1}$, died on the 45th day (Venkatesan, Jayaganesh, 2010). 
Phragmites australis can tolerate many types of habitats and grow in areas with wide ecological amplitude, including wetland and soil. Many studies reported P. australis as one of the best plant organisms for the detection and adsorption of harmful contamination by heavy metals (Wang et al., 2015). P. australis is not a hyperaccumulator; however, this is a fast-growing and high-biomass producer, has a deep root apparatus, and can tolerate and/or accumulate a range of heavy metals in their aerial portion. Given this, this is often utilized to reduce the metal concentration of soils, sediments and waters (Bragato et al., 2006). P. australis has also been used to identify the presence of $\mathrm{Cd}, \mathrm{Cu}, \mathrm{Pb}$ and $\mathrm{Zn}$ in estuaries, suggesting that it can be used as a bio-indicator (Cicero-Fernandes et al., 2017). Agrostis stolonifera and Elytrigia repens are capable of forming tolerant ecotypes and are also characterized by a high ecological valence and resistance to heavy metals (Banásová, 2004; Boguská et al., 2013; Fazekašová et al., 2016). Elytrigia repens is the most resistant to contamination by $\mathrm{Pb}, \mathrm{Cr}, \mathrm{Zn}$, $\mathrm{Mn}, \mathrm{Ni}$, and $\mathrm{Cu}$ and is characterized by low contents of the elements under study compared to the other plant species (Minkina et al., 2017). Ranieri et al. (2013) reports that Phragmites australis has a high potential for adsorption of $\mathrm{Cr}$ from contaminated soils. Charlesworth et al. (2016) state that Agrostis stolonifera has a high accumulation potential for heavy metals. These findings will assist in selecting the best grasses to address the pollution of the urban environment by contaminant particulates.

\section{Conclusion}

The magnesium industry has a negative impact on the basic elements of the environment. The effects of mining and processing activities are physical changes in a surrounding country, holes and craters after surface mining, heaps, waste dumps as well as dustiness caused by the emission of solid particles. A high deposition of dust is accompanied by soil and water contamination with alkali elements. The area Jelšava-Lubeník is one of the most devastated regions of Slovakia, with an alarming degree of environmental damage. The major component of environmental pollution in Jelšava-Lubeník is magnesite powder belonging to aerosol particles. The result is secondary salinization by $\mathrm{Mg}$, chemical intoxication, and soil devastation. A continuous magnesite crust covers a part of the soil; the vegetation cover is considerably eliminated, reducing a landscaping and environmentally aesthetic function and ecologically important soil functions. The research showed that the investigated sites were mostly strongly alkaline, the contents of $\mathrm{Cr}, \mathrm{Mn}$ and $\mathrm{Mg}$ are over the toxicity limit, the measured values of $\mathrm{Pb}$ and $\mathrm{Zn}$ did not exceed the limits set by the law. Their significant surpassing of limits points to contamination, which we consider harmful and toxic. In the monitored species, Agrostis stolonifera, Elytrigia repens and Phragmites australis, over-limit contents of $\mathrm{Pb}$ and $\mathrm{Zn}$ and toxic contents of $\mathrm{Mg}$ and $\mathrm{Mn}$ were found. Based on the results of the Shannon index, we can conclude that the diversity on the investigated sites is extremely low (0.0) to middle low (1.5).

\section{Acknowledgements}

The study was supported by VEGA 1/0127/16, VEGA 1/0934/17 and KEGA 011PU-4/2016. 


\section{References}

Act No. 220/2004 (2004). Coll. of laws on the protection and use of agricultural land. Bratislava: National Council of Slovak Republic.

Adriano, D.C. (2001). Trace elements in the terrestrial environment. Springer: New York.

Baluchová, B., Bačík, P., Fejdi, P. \& Čaplovičová M. (2011). Mineralogical research of the mineral dust fallout from the years 2006-2008 in the area of Jelšava (Slovak Republic). Mineralia Slovaca, 43, 327-334.

Banásová, V. (2004). The unique vegetation on old mining dumps (in Slovak). Chránené Územia Slovenska, 62, $42-43$.

Barančoková, M. \& Barančok P. (2015). Distribution of the traditional agricultural landscape types reflecting geological substrate and slope processes in the Kysuce region. Ekológia (Bratislava), 34(4), 339-355. DOI: 10.1515/ eko-2015-0031.

Barančoková, M., Krnáčová, Z. \& Chasníková S. (2017). Quantification of the natural factors impact effectiveness on environmental hazards - slope movements in the flysch areas of the Kysuce region. Ekológia (Bratislava), 36(3), 197-213. DOI: 10.1515/eko-2017-0017.

Barman, S.C., Kisku, G.C., Salve, P.R., Misra, D., Sahu, R.K., Ramteke, P.W. \& Bhargava S.K. (2001). Assessment of industrial effluent and its impact on soil and plants. J. Environ. Biol., 22, 251-256.

Boguská, Z., Fazekašová, D. \& Angelovičová L. (2013). Diversity of vegetation on contaminated substrates (in Slovak). In Zborník 17. mezinárodní konference o životním prostředí a úpravnictvi (p. 330). Ostrava: VŠB TU.

Bragato, C., Brix, H. \& Malagoli M. (2006). Accumulation of nutrients and heavy metals in Phragmites australis (Cav.) Trin. ex Steudel and Bolboschoenus maritimus (L.) Palla in a constructed wetland of the Venice lagoon watershed. Environ. Pollut., 144, 967-975. DOI: 10.1016/j.envpol.2006.01.046.

Braun-Blanquet, J. (1964). Pflanzensoziologie. Grundzüge der vegetationskunde. Wien: Springer Verlag.

Charlesworth, S.M., Bennett, J. \& Waite A. (2016). An evaluation of the use of individual grass species in retaining polluted soil and dust particulates in vegetated sustainable drainage devices. Environ. Geochem. Health, 38, 973-985. DOI: 10.1007/s10653-016-9791-7.

Cicero-Fernandes, D., Peňa-Fernández, M., Expósito-Camagro, J.A. \& Antizar-Ladislao B. (2017). Long term (two annual cycles) phytoremediation of heavy metal-contaminated estuarine sediments by Phragmites australis. New Biotechnology, 38, 56-64. DOI: 10.1016/j.nbt.2016.07.011.

Climate atlas of Slovakia (2015). Bratislava: SHMÚ.

Čurlík, J. \& Šefčík P. (1999). Geochemical atlas of the Slovak Republic (in Slovak). Bratislava: MŽP SR.

Fazekašová, D., Barančíková, G., Torma, S., Ivanová, M. \& Manko P. (2014). Chemical and environmental aspect of the component of the environment and landscape (in Slovak). Prešov: Fakulta manažmentu Prešovskej Univerzity.

Fazekašová, D., Boguská, Z., Fazekaš, J., Škvareninová, J. \& Chovancová J. (2016). Contamination of vegetation growing on soil and substrates in the unhygienic region of central Spiš (Slovakia) polluted by heavy metals. J. Environ. Biol., 37, 1335-1340. ID: 29261257.

Fiala, K., Barančiková, G., Brečková, V., Burik, V., Houšková, B., Chomaničová, A., Kobza, J., Litavec, T., Makovniková, L., Pechová, B. \& Varadiová D. (1999). Partial monitoring system - soil, binding methods (in Slovak). Bratislava: VÚPaOP.

Gikas, P. \& Romanos P. (2006). Effects of tri-valent (Cr(III)) and hexa-valent (Cr(VI)) chromium on the growth rate of activated sludge. J. Hazard Mater., 133, 212-217. DOI: 10.1016/j.jhazmat.2005.10.023.

Gladkov, E.A., Gladkova, O.N. \& Glushetskaya L.S. (2011). Estimation of heavy metal resistance in the second generation of creeping bentgrass (Agrostis stolonifera) obtained by cell selection for resistance to these contaminants and the ability of this plant to accumulate heavy metals. Applied Biochemistry and Microbiology, 47, 776-779. DOI: 10.15389/agrobiology.2014.4.106eng.

Hohl, H. \& Varma A. (2010). Soil: the living matrix. In I. Sherameti \& A. Varma (Eds.), Soil heavy metals, soil biology (pp. 1-18). Berlin, Heidelberg: Springer Verlag. DOI: 10.1007/978-3-642-02436-8_1.

Hronec, O., Vilček, J., Tóth, T., Andrejovský, P., Adamišin, P., Andrejovská, A., Daňová, M., Huttmanová, E., Vilimová, M., Škultéty, P. \& Juhászová M. (2008). Heavy metals in soils and plants in Rudniansko-Gelnická loaded area. Acta Regionalia et Environmentalica, 1, 24-28.

Hronec, O., Vilček, J., Tomáš, J., Adamišin, P. \& Huttmanová E. (2010). Environmental components quality in problem ares in Slovakia (in Slovak). Brno: Mendelova univerzita v Brně.

Jiang, X. \& Wang Ch. (2008). Zinc distribution and zinc-binding forms in Phragmites australis under zinc pollution. 
J. Plant Physiol., 165, 697-704. DOI: 10.1016/j.jplph.2007.05.011.

Kabata-Pendias, A. (2011). Trace elements in soil and plants. London: CRC Press.

Kafka, Z. \& Punčochářová J. (2002). Toxicity of heavy metals in nature. Chemické Listy, 96, 611-617.

Kobza, J., Barančíková, G., Dodok, R., Hrivňáková, K., Makovníková, J., Mališ, J., Pálka, B., Styk, J. \& Širáň M. (2010). Soil monitoring of Slovakia (in Slovak). Bratislava: VÚPaOP.

Mahmood, T. (2010). Review phytoextraction of heavy metals - the process and scope for remediation of contaminated soils. Soil \& Environment, 29, 91-109. www.se.org.pk

Marhold, K. \& Hindák F. (1998). Checklist of non-vascular and vascular plants of Slovakia (in Slovak). Bratislava: Veda, vydavatel'stvo SAV.

Mazúr, E. \& Lukniš M. (1980). Regional division SSR (in Slovak). Bratislava: Geografický ústav SAV.

Melichová, Z., Ďuricová, A., Samešová, D. \& Nagyová I. (2017). Risk assessment of selected metallic elements in water. Banská Bystrica: UMB.

Mindáš, J. \& Škvarenina J. (1995). Chemical composition of fog cloud and rain snow water in Biosphere Reserve Pol'ana. Ekológia (Bratislava), 14, 125-137.

Minkina, T.M., Mandzhieva, S.S., Chaplygin, V.A., Bauer, T.V., Burachevskaya, M.V., Nevidomskaya, D.G., Sushkova, S.N., Sherstnev, A.K. \& Zamulina I.V. (2017). Content and distribution of heavy metals in herbaceous plants under the effect of industrial aerosol emissions. Journal of Geochemical Exploration, 174, 113-120. DOI: 10.1016/j.gexplo.2016.05.011.

Pant, P.P. \& Tripathi A.K. (2014). Impact of heavy metals on morphological and biochemical parameters of Shorea robusta plant. Ekológia (Bratislava), 33, 116-126. DOI: 10.2478/eko-2014-0012.

Ranieri, E., Fratino, U., Petruzzelli, D. \& Borges A.C. (2013). A comparison between Phragmites australis and Helianthus annuus in chromium phytoextraction. Water Air Soil Pollut., 224, 1465-1474. DOI: 10.1155/2016/9415175.

Shanker, A.K., Cervantes, C., Loza-Tavera, H. \& Avudainayagam S. (2005). Chromium toxicity in plants. Environ. Int., 31, 739-753. DOI: 10.1016/j.envint.2005.02.003.

Singh, R., Chavan, S.L. \& Sapkale P.H. (2006). Heavy metal concentration in water, sediments and body tissues of Red Worm (tubifex SPP) collected from Natural Habitats in Mumbai, India. Environ. Monit. Assess., 129, 471-481. DOI: 10.1007/s10661-006-9377-4.

Song, J., Zhao, F.J., McGraft, S.P. \& Luo Y.M. (2006). Influence of soil properties and aging of arsenic phytotoxicity. Environ. Toxicol. Chem., 25, 1663-1670. DOI: 10.1897/05-480R2.1.

Ševčík, P., Pramuka, S. \& Gluch A. (2008). Assessment of soil contamination in Slovakia according index of geoaccumulation. Agriculture, 54, 119-130.

Škvarenina, J., Tomlain, J., Hrvol, J., Škvareninová, J. \& Nejedlik P. (2009). Progress in dryness and wetness parameters in altitudinal vegetation stages of West Carpathians: time-series analysis 1951-2007. Idöjárás, 113, 47-54.

Špulerová, J. Dobrovodská, M., Lieskovský, J. Bača, A., Halabuk, A., Kohút, F., Mojses, M., Kenderessy, P., Piscová, V., Barančok, P., Gerhátová, K., Krajčí, J. \& Boltižiar M. (2011). Inventory and classification of historical structures of the agricultural landscape in Slovakia. Ekológia (Bratislava), 30(2), 157-170. DOI: 10.4149/ ekol_2011_02_157.

Špulerová, J., Drábová, M. \& Lieskovský J. (2016). Traditional agricultural landscape and their management in less favoured areas in Slovakia. Ekológia (Bratislava), 35(1), 1-12. DOI: 10.1515/eko-2016-0001.

Takáč, P., Kozáková, L', Valková, M. \& Zeleňák F. (2008). Heavy metals in soils in the middle Spiš. Acta Montanistica Slovaca, 13, 82-86.

Vaiopoulou, E. \& Gikas P. (2012). Effects of chromium on activated sludge and on the performance of wastewater treatment plants. Water Res., 46, 549-570. DOI: 10.1016/j.watres.2011.11.024.

Venkatesan, S. \& Jayaganesh S. (2010). Characterisation of magnesium toxicity, its influence on amino acid synthesis pathway and biochemical parameters of tea. Research Journal of Phytochemistry, 4, 67-77. DOI: 10.3923/ rjphyto.2010.67.77.

Vilček, J., Škvarenina, J., Vido, J., Nalevanková, P., Kandrík, R. \& Škvareninová J. (2016). Minimal change of thermal continentality in Slovakia within the period 1961-2013. Earth System Dynamics, 7, 735-744. DOI: 10.5194/ esd-7-735-2016.

Wang, L., Tai, P., Jia, Ch., Li, X., Li, P. \& Xiong X. (2015). Magnesium contamination in soil at a magnesite mining region of Liaoning Province, China. Bull. Environ. Contam. Toxicol., 95, 90-96. DOI: 10.1007/s00128-015-1530-8. 